\title{
『ジェンダー・トラブル』の 〈ジェンダー〉と「身体なるもの」
}

\section{須永 将史*}

ジュディス・バトラーの身体へのアプローチにはどのような意義があるのだ ろうか. 本稿ではまず，『ジェンダー・トラブル』におけるバトラーの身体へ のアプローチに，重要な側面が 3 つあるとを指摘する。 それは，第 1 に，ジ エンダー概念の再定義がなされていることであり，第 2 に, 身体論の主要な論 点を「身体なるもの（= The body）」という論点から「個々の身体（= bodies)」という論点へと移行させようとしていることだ，そして第 3 の側面 は，「身体なるもの」の「内部／外部」の境界が不確定であるという主張がな されていることである.

次に, フェミニズム／ジェンダー論にとっての既存の身体観を整理し，バト ラーが各論者の身体観をどのように批判し，どのように乗り越えようとしたか を述べる. バトラーはボーヴォワールの議論が精神／身体の二元論を保持して いることを批判し, イリガライの議論が生物学的性差としてのオス, メスの二 元論を保持していることを批判する. バトラーのアプローチによると, 2 人が 保持するそうした二元論自体が，問題視されるべきなのである.

本稿では，バトラーの貢献とは次のようなものだと結論する，それはすなわ ち, ジェンダーという概念を再定義することによって, 人々を異性愛の基準に おいてのみ首尾一貫させる現象の水準を指摘しようとしたことだ。また本稿で は, 〈ジェンダー〉を実証的に明らかにするためには，実際の社会において使 用される身体や行為を記述することがフェミニズム/ジェンダー論の今後の課 題であることも示唆する.

キーワード：身体, 行為, ジュディス・バトラー

\section{1 問題の所在}

本稿の目的は, ジュディス・バトラーの身体へのアプローチが, ジェンダー概念 に関する議論において果たした貢献を明らかにすることである，後述するようにバ トラーは, 日本で語られるとき,「構築主義」的アプローチの文脈で語られること

* 首都大学東京大学院人文科学研究科博士後期過程 snms0310@gmail.com 
が多いように思われる，そしてその場合，バトラーのアプローチには身体に対する 配慮がない，という理解が散見される，だが，筆者の理解では，バトラーは必ずし も自らが構築主義者であることを志向してはいない。そしてむしろ筆者は，バトラ 一は身体に積極的にアプローチしているとさえ考えている，本稿では，そうしたバ トラーの, 身体へのアプローチに着目し，フェミニズム／ジェンダー論におけるバ トラーの意義を提示する.

フェミニズム／ジェンダー論はこれまで，長い間身体を論点としてきた，それは 無論, 人々の本質的な差異とは性差であるという主張の論拠が, まさに身体に求め られたからだ。フェミニズム／ジェンダー論が論点としてきたこの身体という語に は,「生物学的性差としてのセックス」もまた含まれる.フェミニズムの分析概念 の 1 つであるジェンダーが，セックスに対抗して導入されたことは，フェミニズム の身体観を明確に表している.

バトラーが示唆する方向は，これまでのフェミニズム／ジェンダー論者の論点を 積極的に引き継いだものだ. 加えてバトラーは, フェミニズム／ジェンダー論の重 要な分析概念であるジェンダーを再定義しようと模索している.そしてその際に, 「身体なるもの」という観念を物質的な論拠として前提することが誤りであると， 注意を促しているのである.

こうしたことを明らかにするために本稿では，2つの作業を行う。第 1 に，バト ラーの身体へのアプローチの内実を明らかにする，第 2 に，そのアプローチにいか なる意義があるかを明らかにする，第 1 の点については，バトラーの身体へのアプ ローチの 3 つの側面を第 2 節で述べる. 第 2 の点については第 3 節と第 4 節で, ボ ーヴォワールとイリガライの身体観を示し, 次いで 2 人の議論をバトラーと比較し, バトラーの意義を述べる.

\section{2 バトラーにとっての身体}

第 1 節で述べたように，この節ではバトラーの身体へのアプローチを明確にする. まず考察の出発点として，金井淑子のバトラー理解を参照しょう。金井はバトラー の議論を, 「ポスト構造主義ジェンダー論の命題, 構築主義を言説一元論まで先鋭 化させた議論」であるとみなしている（金井編 2008：36）。そしてそれに対し金井 自身は「バトラー的ジェンダー論ではどうしても無いとされる物質的な与件性」を 論点とすること,「構築主義が死角化してきた身体を取り落とさない」ことを試み ると主張する．だが金井のいう「構築主義者としてのバトラー」という理解が欠落 させているのは，バトラーの目論見の 1 つがジェンダー概念の再定義にあるという ことだ，金井のような理解が生まれるその根底には，ジェンダー概念に対する次の ような䛊解があるのである.

その誤解とは, バトラーが使用するジェンダー概念はセックスに対して導入され た既存の使用法のままであり，七ックス／ジェンダーの 2 つ項のうち, バトラー 
はジェンダーによる説明を重視し，身体やセックスの物質性を考慮していないとい う誤解である. 既存のジェンダー概念に書き込まれている「文化的・社会的な性 差」という意味作用に主眼が置かれることによって, 前記のような「言説一元論」 という理解が招かれてしまうのである，同様のことは，多くの論者に散見される （上野 2002； ギブソン松井 2002；細谷 2004）.

筆者の理解は, 前記の理解と 2 つの点で異なる. 第 1 に, バトラーはジェンダー 概念の意味そのものを再定義しようとしている，そしてまた第 2 に，バトラーが試 みたのは「身体は物質である/ない」のかという議論ではなく，市市にして身体が 物質的なもうとして論じられ⿱きたうか，という議論である。

\section{1 ジェンダーノセックス/〈ジェンダー〉}

バトラーがまず目を向けるのは，ジェンダーとセックスの概念的な関係である. 既存の定義におけるジェンダー概念とは, セックス ${ }^{1)}$ では記述できない文化的・社 会的に獲得される性差, という意味である. ジェンダーもセックスも説明する領域 は異なるが，女／男の性差を記述するという点ではさしあたり同様の意味作用をも っている. だがこの定義のもとでは，バトラーにならっていえば， ジェシ多・が方

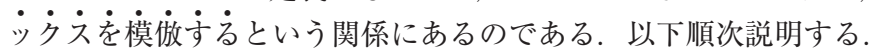

ジェンダーやセックスという語は, G. ルービンのいう「強制された異性愛」 （Rubin 1975=2000：133）という制度のなかで理解されるものにすぎない. 言い換 えれば，セックス，ジェンダー，そしてルービンをふまえればセクシュアリティ， という諸「概念」は，異性愛の基準においてのみ首尾一貫するようにしか使用され ていないのである。 そこでバトラーは，ジェンダーに従来とは異なる意味を加える. すなわちバトラーは，ジェンダーという語に，セックス/ジェンダーが性差を指 し示すこと六のもうを意味する作用を書き加えるのだ．非常に有名になったフレー ズを次に引用する.

It would make no sense, then, to define gender as the cultural interpretation of sex, if sex itself is a gendered category. Gender ought not to be conceived merely as the cultural inscription of meaning on a pregiven sex (a juridical conception); gender must also designate the very apparatus of production whereby the sexes themselves are established. (下線筆者) (Butler 1990: 10 =1999)

2 文目に注目していただきたい，竹村和子の訳では「ジェンダーは，生得のセッ クス（法的概念）に文化が意味を書き込んだものだと考えるべきではない。ジェン ダーは，それによってセックスそのものが確立されていく生産装置のことである」 （Butler [1990]2000=1999：29）となっている. しかし，竹村の訳から， merely と also の意味が抜けていることは，バトラーがこの一文で扔こなっていることを不明 
瞭にしてしまう（Kallikles 2007）。つまり，このように訳すべきなのだ.「ジェン ダーは, たえに生得のセックス（法的概念）に文化が意味を書き込んだものだと考 えるべきではない. ジェンダーはまた, それによってセックスそのものが確立され ていく生産装置のこと㐫ある」」2.

ここから，ジェンダーが 2 通りの意味を担わされていることが解釈できる，それ は第 1 にセックス/ジェンダーのうちの 1 項としてのジェンダーであり, 第 2 にセ ックスを生物学的な性差として取り扱うべく作動するジェンダーである。この第 2 の意味でのジェンダーを加藤秀一にならって構築する〈ジェンダー〉と呼ぼう（加 藤 1997).〈ジェンダー〉の内容をさらに詳しくみてみよう。〈ジェンダー〉がバト ラーにとって重要なのは, それが人々の性差を理解可能にするために産出される規 範だからである.

連続せず首尾一貫していない奇妙な代物は, 連続性と首尾一貫性という既存 の規範の関係によってのみ思考可能となるので, こういった奇妙な代物を常に 禁じると同時に生み出しているのは, まさに, 生物学的なセックスと, 文化的 に構築されるジェンダーと, セックスとジェンダー双方の「表出」つまり「結 果」として性的実践をとおして表出される性的欲望, この 3 者のあいだに因果 関係や表出関係を打ち立てようとする法なのである.（Butler [1990]2000 = 1999: 46)

このようにバトラーは, セックス・ジェンダー・セクシュアリティを女／男の異 性愛の云元論的思考によう 方理解可能にする基準 = 規範（norm）の水準を指摘し ている.〈ジェンダー〉は, その水準をさすために再定義されたのであり，言い換 えるならば〈ジェンダー〉は，セックス／ジェンダーが両方とも女／男を説明する

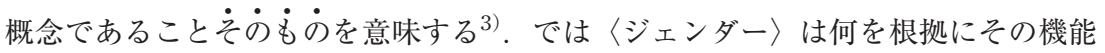
を果たすのか. それは無論, セックスである. バトラーはミシェル・フーコーを介 して次のようにも主張する.

セックスを 2 つに切り分けるカテゴリー化を生産する戦術は, 「セックス」 を, 性的な経験や行為や欲望の「原因」と定めることによって, その生産装置 の戦略的な目的を隠蔽してしまうのである.フーコーの系譜学的な研究が暴い ているのは,「原因」のようにみえるものが, じつは「結果」であるというこ とだ.（Butler [1990]2000=1999: 55）

バトラーのいう〈ジェンダー〉という水準は, フーコーをふまえることでさらに 明確になる.〈ジェンダー〉によってセックスの差異化 $(=\text { カテデリリー化 })^{4)}$ がなさ れる一方, その差異は「原因」として据えられる. 本項の冒頭で述べた「模倣」と は, このことの比喻なのだ. 根拠があることで, セックス・ジェンダー・セクシュ 
アリティの首尾一貫性は理解可能なものとなる. では, そうしたセックスの差異化 はどのような前提のもと根拠づけられているのか. それは「身体なるもの（=The body)」の存在を議論の前提に成立しているのだ.

\section{2 「身体なるもの」／「個々の身体」一七ックスの物質性}

第 2 の点に移る．ここでは，〈ジェンダー〉の前提に「身体なるもの」（以下， 「身体」）を置くことに対する，バトラーの批判をみる．そしてバトラーはフーコー を参照し，「身体」をデカルトに由来する観念的なものと捉え，「個々の身体」のジ エンダー化へと分析を進めることを提案する。まずバトラーの，「身体」という前 提の批判を見よう.

セックス／ジェンダーの区別や, セックスというカテゴリーそのものは, 性 別化された意味を獲得するまえの「身体なるもの」の普遍性を前提としている ように思われる：こういった「身体なるもの」はたいてい受け身の媒体で，身 体の「外部」と考えられている文化的要素からの書き込みによって，意味づけ られるもののようである. (Butler [1990]2000=1999: 229)

サルトルとボーヴォワールの著作のなかには,「身体なるもの」を無言の事 実性とみなす箇所が数多くあり，「身体なるもの」が意味を与えられるのは， デカルト的な文脈のなかで根本的な非物質性と考えられている超越意識によっ てであると考えられている.（Butler [1990]2000=1999: 229）

ボーヴォワールについては 3 節で詳しく述べるので, ここでは必要な部分のみ述 ベる，バトラーはここで, ジャンーポール・サルトルやボーヴォワールがもつ身体 観を次のような理由で批判している.

まず 2 人の考え方に，精神／身体のデカルト的二元論が見出せる. 2 人にとって， 「身体」は「精神」によって意味づけられ，普遍的な事実として存在しているのだ. 言い換えれば「身体」とは，それに対して「精神」を上位に据えるための議論の 「前提」として，それ以上問われてこなかったのだ.

だがこの「身体」とは，結局のところ観念的なものでしかない.「まず身体その ものがあって, その諸性質があるのではない. さまざまな性質の総和, 諸活動の把 捉しがたく動きつづける連鎖だけが現実の，〈物質的な〉ものとしての身体」なの である（加藤 2001：181）.「身体なるもの」の存在を前提に, その表現としての諸 性質を考察する，という思考手続きは誤りなのだ。

こうしたバトラーの身体観もまた，フーコーを参照している（Foucault 1976= 1986：191）。フーコーが描こうとした歴史とは，すでに確立した様式をもつ「身 体」の歴史ではない，フーコーは，様式が確立させられるための部品となる具体的 な，生々しい身体の歴史を描こうとした。言い換えればフーコーは，言説の「まえ 
に」あるとされる「身体」を「観念」と捉え, むしろ具体的な身体がいかにして 「権力のさまざまな戦略を通して形成されてきたか」を問うのだ（Foucault 1976= 1986: 192).

バトラーは, このフーコーの認識を応用し，「身体 (=The body)」／ジェンダ 一化される「個々の身体 (=bodies)」という枠組みを提示しているのだ.

「身体なるもの（=The body）」は，ジェンダー化された主体領域を構築し ている無数の「個々の身体 (=bodies)」と同様に, それ自体が構築されたも のである. ジェンダーのしるしが付けられる以前に, 意味ある実在が個々の身 体のなかにあったと言うことはできない.（Butler [1990]2000=1999: 32）

ここでバトラーは,「身体」は構築されたものであると批判する一方で, 〈ジェン ダー〉が作動する対象領域が「個々の身体」であり，そのジェンダー化に寄与して いることを強調している，その後書かれた（Butler 1993）では，「個々の身体」の セックスの「物質性」がいかに物質化してきたか論じている5).そこでは「身体」

「個々の身体」の枠組みから, さらに「個々の身体」における「セックスの物質 化」の過程に迫ろうとするのだ.

異性愛体制はセックスの「物質性」を枠づけ，その輪郭を定めるべく作動す るが,ここでいう「物質性」とは部分的には異性愛のへゲモニーの諸規範であ るところの諸規範の物質化を通じて, また物質化として, かたちづくられ, 維 持されるものである。（Butler 1993：15）

だがこの点については, 紙数の関係上これ以上本稿では問わない. 今のところ重 要なのは, バトラーが,〈ジェンダー〉が規範として作動する領域は「個々の身体」 だと認識していることである。ここまでの議論をいったんまとめよう。再定義され た〈ジェンダー〉は次のような機能を果たす。それはセックスを根拠に, セック ス・ジェンダー・セクシュアリティを異性愛の枠組みにおいて一貫させる．セック スが根拠となるのは，そもそも普遍的な「身体」を議論の前提にするからである. つまり，ひとの「身体」にセックスという差異を見出し，「個々の身体」を異性愛 の枠組みで把捉するように規範的に機能しているのが〈ジェンダー〉なのだ6).

では「個々の身体」のジェンダー化について，バトラーはどのように考えている のか.

「身体」の輪郭は, どのように，そのうえにジェンダーの意味が書き込まれ る自明の下地や表面—つまり意味に先立つ価值不在の単なる事実性—— して，はっきりとしるしづけられているのか. (Butler [1990]2000=1999: 230) 
ここでバトラーがいいたいのは，「身体」の輪郭とは，たんなる事実性ではなく， 「内部／外部」に区別することが可能であり，その区別が価值付与を伴うというこ とだろう。先取りになるが，バトラーが論点にしたいのは「身体」の輪郭に，その 内部に見出さ礼方重要な意味之して「性別」があることであり, それが「個々の 身体」において規範的に作動することが重要なのではないだろうか. 筆者の理解で は，この点がバトラーとフーコーの決定的な差異であり，バトラーの目を「行為」 に向けさせた点である.

\section{3 輪郭 /内部 / 外部-行為}

ここで第 3 の点に移る，バトラーは，「身体なるもの」の「内部」と「外部」を 境界づける「輪郭」が不確定であることを論証しようとする．たとえば，「心」と は一般的に「身体」の内側にあると考えられている．より正確にいえば，「心」と いう言葉が使用されるとき，皮膚の内側にある〈なにか〉を前提しながら使用され ている，その際，「身体」の内面に〈なにか〉を想定するためには，内面に対する 外面, 内面と外面を隔てる境界がなければならない。 そういった区別, 内面と外面 の差異化をしなければ,「身体」という領域の「内部」に「心」は確保できないだ ろう。だがバトラーは，ジュリア・クリステヴァの棄却の議論などに触れながら, 次のように述べる.

内部と外部の世界がまったく別物でありつづけるためには，「身体」の表面 すべてが非浸透的になるという，不可能を達成しなければならない。こうして 表面を完全に封じることによって, 主体の継ぎ目のない境界を構築することが できる、だがこの封じ込めは，それが恐れている排便という污物のために，か ならず破られてしまう.（Butler [1990]2000=1999: 236）

バトラーにとって，「身体」の「内部」と「外部」の境界は明暸にひかれたもの ではない.「内部」にある〈なにか〉とは, その「外部」との関係においてのみ思 考しうるのだ，つまりバトラーは，境界を定めるうとによう「内部」が構築されて きたと考えているのだ。言い換えれば，「内部」はいかに「内部」化し，「外部」 はいかに「外部」化したのか，を問うているのである。そしてこれらは同時に問わ れねばならないのである。なぜなら「内部」の歴史だけを問うこととは，「内部」 を論証の前提とすることを意味するのであり, その場合,「内部」化と「外部」化 の過程を不問にすることにほかならない.

問題は，公的言説のなかのどんな戦略的な位置のために，またどんな理由の ために，内面というたとえや，内部／外部の不連続な二元論が定着してきたか ということである.どのような言語において「内なる空間」という比喻が語ら れるのか. それはどのような種類の比喻化なのか. 身体のどんな比喻をとおし 
て，それは意味づけられるのか、いかに身体はその表面のうえに，隠された深 部の不可視性を形象しているのか.（Butler [1990]2000=1999：237）

バトラーがこの「内部」と「外部」の不確定性を問題にするのは，内部空間とし ての「心」を問題にしたいからだけではない。「性別」もまた，われわれの「個々 の身体」の「内部」にその因を求めることが可能であるかのように論じられてきた からである. なぜならここにおいて二元論的な〈ジェンダー〉が作動しているから である。

それは，「身体」の表面の政治をつうじてなされる幻想の公的な規制であり， また，内部と外部を差異化し，それによって主体の「全一性」を定めるジェン ダーの境界管理であるということだ（Butler [1990]2000=1999: 240）

「身体」は，われわれの「個々の身体」の「内面」に「性別」を付与するために 決定的に重要な前提なのではないだろうか.「身体」の「内部」と「外部」を隔て る輪郭を定め, 意味づけし, 異性愛という枠組みでのみ理解できるように「『個々 の身体』を自然に配置していく」のが〈ジェンダー〉なのだ（Butler [1990]2000 = 1999: 246).

どのような目的で，「身体」の境界，「身体」を「内部／外部」に隔てる輪郭が形 成されてきたのか. バトラーのこの問いは, 同時にバトラーの戦略の方向性を内包 したレトリカルな問いでもある.つまり,「身体」の輪郭の「内側」「精神」アイデ

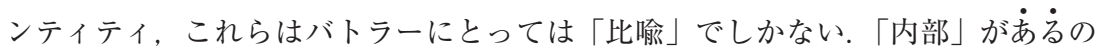
ではなく，むしろ行為を成し遂げる「身体」に，「内部」が投影されているのだ.

行為や身ぶりや欲望によって内なる核とか実体という結果が生み出されるが, 生み出される場所は，身体の表面の方它方う，しかもそれがなされるのは， アイデンティティを原因とみなす組織化原理を暗示しつつも顕在化させない意 味作用の非在の戯れをつうじてである。（Butler [1990]2000=1999: 239）

バトラーにとって「内部」は体内に方方のではない，バトラーは，身体の表面の うえに,つまり輪郭の外側に現れる現象に,「内部」としての「内なる核」や「実 体」が投影されていると主張する。したがってバトラーの主張する摚乱戦略とは, 行為によって精神／身体，「内部／外部」の不確定性をあらわにし，それによって， われわれがいかに〈ジェンダー〉の, 規範としての一貫性を自明視しているかを顕 現させる戦略なのである.

以上，バトラーの身体へのアプローチを 3 つの枠組みで把握してきた．第 1 に， ジェンダー概念の再定義であり，第 2 に，「身体」の批判がなされた，そして第 3 に,「身体」の「内部／外部」の境界が不確定であるという主張をみた ${ }^{7)}$. 
こうしたバトラーのアプローチの意義を明確にするために，以下では，バトラー がフェミニズム／ジェンダー論者をどのように理解し，批判したかを検討する.

\section{3 バトラー/ボーヴォワール}

\section{1 ボーヴォワールにみる「他者」}

ボーヴォワールは『第二の性』の序文で次のように述べる。「女は本質的なもの に対する非本質的なものなのだ，男は〈主体〉であり，〈絶対者〉である。つまり， 女は〈他者〉なのだ」(Beauvoir 1949a = 2001：15)。ここで，女は〈男という主 体〉に対する〈他者〉と定義されている，それは「男が自分自身を見いだすための 仲介となる一人の〈他者〉」（Beauvoir 1949a = 2001：128）という意味においての 〈他者〉である。ボーヴォワールの出発点は，「男 = 主体」と「女 =他者」という定 義であり，『第二の性』はそれを克服しょうとした試みでもある.

この定義は，「文明全体が，男と去勢者の中間物，つまり女と呼ばれるものを作 りあげるのである」（Beauvoir 1949b=2001：12）という認識に基づいている．ボ ーヴォワールにとって「女になる（＝他者になる)」というのは，正確にいえば社 会によう它規定されるうとを意味する，言い換えれば，女に「なる」とは，同時 に女として「つくられる」ことを意味するのである.

ひとが「女＝他者」として社会的に規定されることを，ボーヴォワールは実存主 義の「実存は本質に先行する」というテーゼによって乗り越えようとした。『第二 の性』の序文で，彼女は次のように書く。

私たちが採用する観点は実存主義のモラルの観点である。すべての主体は 様々な投企を通して具体的に自分を超越として立てる，すべての主体は，新た な自由に向かって絶えず自分を乗り越えることによってはじめて, 自由を実現 する．果てしなく開かれた未来へ向けての発展こそが，現に生きている実存を 正当なものにするのだ．（Beauvoir 1949a = 2001：37）

このボーヴォワールの試みは，彼女が身体にういで論に゙たことに目を向けること でより明確になる。ボーヴォワールは身体について，「女も，男と同じょうに，自 分の身体である。しかし女の身体は女自身とは別のモノなのである」(Beauvoir 1949a=2001：81）と述べている．女の身体は女自身とは別のものであれば，女は その身体をどう考えてゆくべきなのか．さらにボーヴォワールの言葉を引こう．

身体だけでは，やはり，女を定義することはできない，身体は，行動を通じ て，社会のなかで，意識によって引き受けられる限りにおいてのみ，生きた現 実性をもつのである。（Beauvoir 1949a=2001：93） 
女は身体をもち，その身体を意識によう方引き受けることで「生きた現実性」を もつ. このことは, 両義的な意味をもっている. つまり, 社会において, 女市身体 によって／として，女になる/つくられる，ということなのである，その身体につ いての両義性を, 女自身は, 意識によって引き受ける. トリル・モイはこの点につ いて，「したがって女たちが自分の身体をどのように経験するかが，女たちの主体 性や世界認識に，どうしても影響を及ぼすことになる」（Moi 1994=2003：343）と 述べる.

筆者の理解では, ボーヴォワールの『第二の性』の重要な意義は, 「女」が, 身 体によって/として, 女になる/つくられる, という両義性をそのまま描ききった ことだ。事実『第二の性』で描かれるのは, 子ども時代から老年期に至るまでの, 日常的な社会で起こる具体的な「女の」身体的経験であり, そのような身体的経験 に伴う心的な葛藤である.

井上たか子は, 「女とは何か」という問いについて, 『第二の性』には「矛盾した 要素が含まれている」という（井上 1998: 53）。それは要約すれば, (1)女も男も同 じょうに主体であり,「女らしさ」という本質はない, (2「女」は社会的構築物で ある，(3)女男の身体には差異がある，の3つである（井上 1998）.

この「矛盾」という言葉には語弊があるだろう。だが井上とともに筆者が強調し たいのは，ボーヴォワールが『第二の性』で「女の身体」に関わる両義性がいかに 複雑であるかを示したことである，ボーヴォワールの重要な試みとは，身体を積極 的に論点とすることで,「女」が社会に「つくられる」ことに伴う葛藤を告発して いたことなのだ。モイは次のように書く.

もし人間の条件というものが両義性と葛藤によって特徴づけられたものであ れば, そしてもしその身体構造と生物学と社会的状況によって女が男よりも両 義性と葛藤にさらされているというのであれば, 家父長制のもとで女は人間の 条件を男よりも完全に体現している，ということになる，実際，これがまさに ボーヴォワールが論じていることなのだ.（Moi 1994=2003: 345）

ボーヴォワールは複雑な身体経験と, 社会によって押しつけられる「女」に対し, 「こうした女の条件のもとで，どうすれば女は 1 人の人間として自己実現できるの だろうか」（Beauvoir 1949a＝2001：38）ということを考え抜き，女たちに与えら れている世界を女の視点からありのままに描くことを試みたのではないだろうか.

\section{2 バトラーのボーヴォワール批判}

ボーヴォワールにとって身体が重要な論点だったことを述べた．ボーヴォワール の主張がフェミニズム／ジェンダー論にとってどれほど有意義だったかは，これ以 上本稿で論じる必要はないだろう.

バトラーは，ボーヴォワールの主張を次のように解釈している。 それはボーヴォ 
ワールの主張が「女の身体は女の自由の場や手段にならねばならず，女を境界づけ たり，限界づける女の本質となってはならない」というものだ（Butler [1990] $2000=1999$ ：37）。つまりボーヴォワールは，女の身体とは「自由」になるための 手段であるべきで，女を限界づけるものであってはならない，と主張した，バトラ 一はそう理解している.

この点は筆者が 3.1 項でみたボーヴォワール理解と通じる.すでにみたように, ボーヴォワールは，「どうすれば女は 1 人の人間として自己実現できるのだろうか」 （Beauvoir 1949a=2001：38）を考え，複雑な身体経験を緻密に描いていた.

だが，バトラーは，いったんそのように理解したうえで，次のような批判をボー ヴォワールに向ける，それはボーヴォワールが，「女の身体」と「自由」を垂直な 上下関係として捉えてしまっているという批判だ，身体を自由になる「ための」場 として，自由のための手段として考えるかぎり，身体之自由亣分断さ礼た異なる対 象之它前提せざるを方なくなるからだ。

バトラーは，「自由と身体というデカルト的な二分法を無批判に反復しているた めに，その理論には明らかに限界がある」と考えているのである（Butler [1990] $2000=1999$ : 37)．ボーヴォワールが「女」の身体性を描くことは，「女」を身体性 六の方として捉えることを無自覚に行っていると, バトラーは主張しているの だそそうした「女＝身体性」という認識は，「男」を「自由」ないし「精神」とし て認識していることを反映している，そしてその認識は，デカルト的な二元論，つ まり「文化の中で精神が男性的なものに，身体が女性的なものに結びつけられてき た」ことを「反復」しているというのだ（Butler [1990]2000=1999: 37).

バトラーにとっては, こうしたボーヴォワールの議論に, 男/女, 主体／他者,

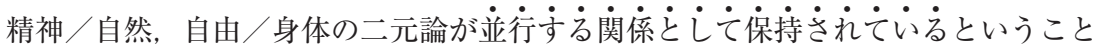
が問題なのだ.

ボーヴォワールの場合,「身体」は言説の構築物であり，「自由」とは無縁だ ということから一歩進んで，精神／身体の区別はジェンダーの非対称の執拗さ を示すものと捉えて，それをジェンダーの軸にそって着目していくことはでき なかった. (Butler [1990]2000=1999: 37)

したがって，バトラーがボーヴォワールに求めたのは，精神／身体の区別そのも のに異議を唱えることだった．なぜならバトラーは，ジェンダーの非対称性とは精 神／身体の二元論そのものに由来すると考えていたからである.

\section{4 バトラー/イリガライ}

\section{1 イリガライと「女性的なもの」}

つぎにイリガライの身体観を考えてみよう，イリガライの議論ではセックスの差 
異が重要な論点となってゆくことを前もって喚起しておく，イリガライはまず，言 説の歴史から性的差異を論じはじめる.

主体はつねに男性型で書かれてきたこと, すなわち人間〔男〕が再解釈され なければなりません. だからといって, 人間は一一少なくともフランス語に おいては一一中性であるのではなくて，有性であることには変わりません， 人間 =男は理論的, 道徳的, 政治的な言説の主体でした。 (Irigaray 1984: 5= 1986)

3.1 項のボーヴォワールの認識では, 男／女は主体／他者と並行関係にあったと いえる. しかしイリガライの場合, 男／女と主体／他者は並行する関係にはない. イリガライにとって, ボーヴォワールの認識における他者とは, 人間＝男の言説に よって産出されるものでしかないのだ。一方イリガライにとっての他者とは, 「私 にとって永久に知ることのできない他者, それが私とは性的に異なる他者」 (Irigaray 1984: 15=1986）なのである.

それに対しイリガライが取る戦略とは，端的にいえば女にしか担えない「女性的 なもの」を創造することにある. イリガライは,「女性性（=féminité）」と「女性 的なもの (=féminin)」を区別する.「女性性」とは, 人間＝男の言説のなかで語 られるものである. それはボーヴォワールの「男＝主体」と「女＝他者」に対し 「男性性」／「女性性」のように並行する関係にあり，簡潔にいえば「女性性」は, 社会によって規定される「女」のことだ.

だが，その関係には本当の意味での女の場はないのである，女の場がないことを イリガライは「包むもの」という女性器の比喻で語る. そこでイリガライは人間= 男の言説から抜け出る「女性的なもの」を創造しょうとする，イリガライにとって， 性的な平等を要求することはむしろ人間＝男の言説に参加することである．だから 「女性の搾取の問題は, 性的差異に基づいているし, 性的差異を通してしか解決し ない」(Irigaray 1990=1993：4）のだ.では，性的差異を通してどのように女性の 搾取の問題を解決するのか. どのように「女性的なもの」を創造していくのか.

イリガライによれば，女のセクシュアリティもまた「常に男を基準として」考え られてきた (Irigaray 1977=1987：23). それに対する「女性的なもの」の創造に おいて, 重要な鍵になるのが女のセクシュアリティである. とくにイリガライにと って, ふたつの (陰) 唇の比喻は重要である.

女は絶えず《自己と触れ合って》おり，しかも，それを禁じることはできな い. というのも，女性性器は絶えず口づけしあうふたつの唇でできているから である、だから，ひとりの女において，女はすでにふたり，しかし，ひとりず つに分離できない，愛しあうふたりなのである。（Irigaray 1977=1987: 24） 
イリガライが上記の隠喻で表現しているのは，女のセクシュアリティの多椂性だ. つまり,「女の快感の地理は想像されるより，はるかに多様で，たがいに異なり， 複雑で, 微妙」(Irigaray $1977=1987 ： 31$ ) である，ということである. そしてそ れは「同一者に少々集中しすぎた想像界の中で.......想像される以上に」(Irigaray $1977=1987:$ 31）複数なのである.

身体という問題においてイリガライがとった戦略は, 性器的・生物学的性差 $(\dot{=}$ セック六）を徹底的に「利用」したことだ，ひとの本質的差異を性差に見出すこ とに対し，ボーヴォワールが平等であることを求めた一方で，イリガライは，セッ クスの根拠の 1 つとなりうる性器を隠喻としてセクシュアリティを語り, 男中心に 構成された言説の意味空間を問い直し，女にしか担えない言説（=女性的なもの） の産出を図ろうとしたのである ${ }^{8)}$.

\section{2 バトラーのイリガライ批判}

ここではバトラーのイリガライ批判について述べる，バトラーは， セックスの考 え方についてイリガライを批判する．人間＝男の言説に女の場がないことに対し， イリガライのとった戦略は, 生物学的な性差としてのセックスを比喻的に利用して 「女性的なもの」を産出するという方法だった。

だが, バトラーにとって，イリガライもまた盆路に陥っているのだ。バトラーは イリガライの議論の前提に,「セックスは覇権的な言語の中で実体として見えてい る——形而上学的に言えば，自己同一的な存在として見えている——いう考え 方」(Butler [1990]2000=1999: 49) があることを問題視する.イリガライのよう に語るためには，生物学的性差は「差異」でなければならない，つまり女と男の差 異を語るために，生物学的性差としてのセックスが異なることを前提しなければな らないのである.

イリガライの見方では, ジェンダーに関する実体的な文法は, 男と女を想定 し，それらの属性として男性的なものと女性的なものを想定しているので，男 中心の単声的で覇権的な言説, つまり男根ロゴス中心主義をうまく隐蔽して, 女性的なものを破壞的な多様性の場所に押し込め沈黙させる二元的な考え方の, ひとつの例なのである. (Butler [1990]2000=1999: 49)

言説という領域においては，イリガライはそこに女の不在を見出し，そこで語ら れる《他者》は「女性性」であり, それは一方的に表象される存在であることを暴 いたかもしれない。「女性性」は人間＝男の言説によって生産されるのであり，そ こに女の居場所はない.

しかし，それに対してイリガライのとる戦略もまたバトラーにとっては問題なの である，なぜなら，実体的な文法，実体としてあるセックスを想定し，「女性的な

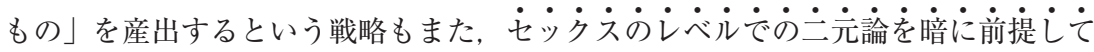


い்からである.

\section{5 結 語}

本稿では，バトラーの身体へのアプローチに 3 つの側面があることを指摘した 第 1 に, ジェンダー概念の再定義, 第 2 に,「身体なるもの」の批判, そして第 3 に,「内部」と「外部」が不確定であるという主張である. バトラーのアプローチ をまとめると，次のようにいうことができる．「身体なるもの」を議論の前提とす る異性愛的な枠組み（〈ジェンダー〉）によって，われわれの「個々の身体」に対 し，性別がその本質として付与されてきた．また「身体なるもの」という議論の前 提は観念にすぎないにもかかわらず，その「内部」と「外部」を隔てる輪郭は明確 なものとして扱われてきた. そこでこうした身体観を脱し, 行為の水準で議論を進 めなければならない。 このようなアプローチのもとでは, ボーヴォワールやイリガ ライの議論にはまだ不足する点があり, バトラーがこと身体という問題について意 義ある知見を述べていることを本稿では示してきた.

以上のような議論を踏まえた場合，バトラーをどのように位置づけることができ るだろうか. 冒頭で触れたようにバトラーは「社会的に構築される文化的性差とし てのジェンダーと生物学的性差としてのセックスの 2 つの項のうち, バトラーは前 者のジェンダーによる説明を重視し, 物質性としてのセックスを考慮していない」 と理解される場合があった.

それに対し, 本稿で示してきた筆者の理解は, 次の点で前記の理解と異なる. バ トラーの意義は, フェミニズム／ジェンダー論者にとってつねに論点であったセッ クスの差異と物質性という問題に, その問題構成の枠組みそのものを産出する生産 装置としての〈ジェンダー〉を示したことだ。言い換えれば, ジェンダー概念の再 定義を試み，セックス・ジェンダー・セクシュアリティを首尾一貫させる機能をも つ〈ジェンダー〉という現象の水準を指摘したのであり，セックスや身体の問題を 無化しようとしたわけではない.

『ジェンダー・トラブル』に関する「誤解」に，バトラー自身も以降の著作で反 論している，その「誤解」の主な原因は「構築」という語の曖昧さにある．たとえ ば, 2.2 項で論じた「身体なるもの」と「個々の身体」に対し，バトラーは両者と もに「構築される」という語を使うのである.

「構築」という語の問題点はそれだけではない.「構築されないもの」がなんであ るかを具体的に思考することが不可能になる点も指摘しておいたほうが良いだろう. たとえばバトラーは，議論のレベルによって，思考体系から「排除（=abject）さ れた存在者」(Butler [1990]2000=1999，1993）を示唆しようとする場合もあれば, 端的にセクシュアルマイノリティをさす場合もある（Butler 2004=2008）.

この曖昧さは, 構築されるもの/されないものの間の線引き問題に対する, バト ラーなりの配慮であり, バトラーの意図は線引きそのものの問題化にこそある, と 
解釈することもできる，にもかかわらず，曖昧さは拭えない．

そういった点に留保をつければ，筆者は『ジェンダー・トラブル』の身体へのア プローチには価值があると考えている，その価值とはやはり，「身体」に性差の根 拠を求めようとする朹組みから，「個々の身体」の「行為」に論点を移そうとする 試みに見出されるべきである。

もしもそれが，それらの起源のようにふるまう首尾一貫したジェンダー主体 を生産するものならば, どんな種類のパフォーマンスが, この一見して「原 因」のように見えているものがじつは「結果」であることを明らかにしていく のだろうか（Butler [1990]2000=1999: 246）

バトラーは「個々の身体」の「行為」に表れる〈ジェンダー〉を，「行為」によ って「攪乱する」という戦略を提案する。今後問うべきは，この戦略の妥当性だろ $j^{9)}$. バトラーの戦略とは，粗描すれば，われわれが自明視する〈ジェンダー〉を 逆に利用し，その規範に不整合をきたす「行為」によってその規範としての一貫性 をあらわにする戦略であり，それによって，〈ジェンダー〉が物質化してきたこと， つまり異性愛的な制度が歴史や慣習として扱われてきたことを，攪乱するのである.

筆者はバトラーのこの戦略を性急なものと考えている。なぜならバトラーは物質 化した異性愛的な制度における「行為」とはどのようなものなのか，またはどのよ うな種類の「行為」を攪乱と呼ぶことが可能なのか, を十分に論証していないから である。むしろバトラーが次に問うべきは，そうした種類の問いであり，実際の 「行為」に即した論証がなされてよいはずだったのだ。こうした問いに部分的に答 えることは, たとえば「行為」と, その都度見出すことのできる性別規範やアイデ ンティティの関係性を検証することによっても可能だろう。そういった，バトラー のいう〈ジェンダー〉の内実を明らかにしてゆく研究が待たれているのではないだ ろうか.

\section{[注]}

1）本稿におけるセックスとは，生物学的性差という意味で用いる.

2）以下のバトラーの引用は，竹村を参照したうえで，必要に応じて訳語等を改訳する.

3）〈ジェンダー〉のこのような機能は，フーコーが（Foucault 1976=1984）で述べた法の産出 機能と排除機能という二重の機能に着想を得ている.

4）たとえば，バトラーが疑義を差し挟む，セックスの差異化のプロセスの一例とは，TDF（精 巣決定遺伝子）に関するものである.（Butler [1990]2000=1999: 191-2)

5）この著作でバトラーは,「構築」という語に向けられた批判に答え, 構築の概念に代えて物 質（matter）という観念に立ち戻ることを提案している. 結語参照. だが「物質化」という概 念にもまだ「曖昧さ」という問題は残るだろう。この点は別稿で論じる.

6）「身体」を批判することは，身体の物質性を否定することとは異なる。バトラーはその後の 著作（Butler 1993）では，「個々の身体」がいかに物質化したかを問う。「時間を貫いて安定を 
保ち, 私たちが物質と呼んでいる境界線, 固定性, 表面をその効果として生み出す物質化のプ ロセス」が「フーコー的な意味での統制的権力の生産的な, まさしく物質化をすすめる諸効果 との関連において考察されるべきである」と考えているのである（Butler 1993: 9-10).

7）ここでバトラーが「個々の身体」による「行為」を決定的に重要な概念と考えていることは 明らかであり, 『ジェンダー・トラブル』以降の議論は, その延長線上にある。 たとえば『触 発する言葉』では「身体が発話行為を行う際, 身体は常にその発話行為を修辞的に超えてしま っている」と述べている，この議論はフーコーとは異なる身体への着眼であり，こうした performativity 概念による「攪乱戦略」の実践の可否は, それ自体で論じるべき課題であるので, 別稿に譲る.

8）以上のイリガライの「本質主義」をD. フスは政治的に理解すべきだとし, 加藤秀一は「本 質主義を酷使しながら本質主義を乗り越える」と解釈している（Fuss 1989; 加藤 1997).

9）バトラーのこの戦略の鍵となる概念が performativity 概念であり，バトラー $(1993,1997)$ では performativity 概念を用いてその戦略が展開されている。 また，バトラー（1999）では, ブルデューのハビトゥス概念を換骨奪胎しつつ活用し, performativity 概念を彫玩しようとし ている.

\section{[文献]}

Beauvoir, Simone de, 1949a, Le deuxiéme sexe I: les faits et les mythes, Paris: Gallimard. (=2001,

『第二の性』を原文で読み直す会訳『第二の性 I 事実と神話』新潮社. )

— 1949b, Le deuxiéme sexe II: l'expérience vécue, Paris: Gallimard. (=2001, 『第二の性』を 原文で読み直す会訳『第二の性 II 体験（上巻)』新潮社. )

——, 1949c, Le deuxiéme sexe II: l'expérience vécue, Paris: Gallimard.（=2001，『第二の性』を 原文で読み直す会訳『第二の性 II 体験（下巻)』新潮社. )

Burr, Vivien, 1995, An Introduction to Social Constructionism, London: Routledge. (=1997, 田中一 彦訳『社会的構築主義への招待——言説分析とは何か』川島書店. )

Butler, Judith, [1990] 2000, Gender Trouble: Feminism and the Subversion of Identity, New York/ London: Routledge. (=1999, 竹村和子訳『ジェンダー・トラブル—フェミニズムとアイデ ンティティの攪乱』青土社. )

—, 1993, Bodies that Matter: On the Discursive Limits of 'Sex', New York/London: Routledge.

- 1997, Excitable Speech: A Politics of the Performative, New York/London: Routledge. (= 2004, 竹村和子訳『触発する言葉——言語・権力・行為体』岩波書店.)

— , 1999, “Performativity's Social Magic," Richard Shusterman ed., Bourdieu: A Critical Reader, Oxford: Blackwell: 113-28.

, 2004, “Gender Regulations,” Undoing Gender, London/New York: Routledge, 40-56. (= 2008 , 越智博美訳「ジェンダーを規制するもの」『述 2 生政治』明石書店／近畿大学国際人文 科学研究所, 172-94.)

Foucault, Michel, 1976, L’histoire de la sexualité, I, La volonté de savoir, Seuil.（=1986, 渡辺守章訳

『性の歴史 I 知への意志』新潮社. )

Fuss, Diana, 1989, Essentially Speaking: Feminism, Nature and Difference, New York: Routledge. ギブソン松井佳子，2002，「バトラー理論の新たな倫理的ビジョン」金井淑子・細谷実編『身体の エシックス/ポリティクス——倫理学とフェミニズムの交叉』ナカニシヤ出版. 
細谷実, 2004,「身体はどのように問題なのか——J・バトラー他に抗して」フォイエルバッハの会 編『フォイエルバッハ——自然・他者・歴史』理想社.

井上たか子, 1998, 「現代フランスの女性思想—シモーヌ・ド・ボーヴォワールからクリスティ ーヌ・デルフィへ」『フランス哲学・思想研究』3: 47-61.

Irigaray, Luce, 1977, Ce sexe qui n'en est pas un, Éditions de Minuit. (=1987, 棚沢直子・小野ゆり 子・中嶋公子訳『ひとつではない女の性』勁草書房.)

—, 1984, Éthique de la différence sexuelle, Éditions de Minuit. (=1986, 浜名優美訳『性的差 異のエチカ』産業図書. )

— 1990, Je, tu, nous: pour une culture de la différence, Paris: Éditions Grasset et Fasquelle. (=1993, 浜名優美訳『差異の文化のために一—わたし, あなた, わたしたち』法政大学出版 局. )

Kallikles, 2007,「北川東子先生のポエム」『Kallikles の目のなかの丸太日記』（2011 年 10 月 8 日 取得, http://d.hatena.ne.jp/kallikles/20070520/p1).

金井淑子編，2008，『身体とアイデンティティ・トラブル—ージェンダーノセックスの二元論を超 えて』明石書店.

—， 2002，「身体・差異・共感をめぐるポリティクス」金井淑子・細谷実編『身体のエシッ クス/ポリティクス——倫理学とフェミニズムの交叉』ナカニシヤ出版.

加藤秀一, 1997, 『性現象論——差異とセクシュアリティの社会学』勁草書房.

—, 2001, 「構築主義と身体の臨界」上野千鶴子編『構築主義とは何か』勁草書房.

Moi, Toril, 1994, Simone de Beauvoir: The Making of an Intellectual Woman, Oxford: Blackwell. (= 2003, 大橋洋一・片山亜紀・近藤弘幸・坂本美枝・坂野由紀子・森岡実穂・和田唯訳『ボーヴ ォワール——性知識人の誕生』平凡社. )

Rubin, Gayle, 1975, “The Traffic in Women," Renya R. Reiter ed., Toward an Anthropology of Women, New York: Monthly Review Press.（=2000, 長原豊訳「女たちによる交通一一性の 『政治経済学』についてのノート」『現代思想』28(2): 118-59.)

上野千鶴子, 2002, 『差異の政治学』岩波書店.

(原稿受付 2010.12.23 掲載決定 2012.5.18) 


\title{
“The Body" and "Gender" of Gender Trouble
}

\author{
SUNAGA, Masafumi \\ Tokyo Metropolitan University \\ snms0310@gmail.com
}

This paper revisits Butler's argument on body discussed in Gender Trouble by first highlighting three important dimensions of her approach to body: the redefinition of "gender," the paradigmatic shift from "The Body" as one entity to individual "Bodies," and her argument concerning the vague boundary between "Inner" and "Outer."

Next, reviewing contemporary views on body in feminism/gender theories, this paper describes Butler's critical arguments. For example, Butler first criticized Beauvoir's approach through the mind and body dichotomy and challenged Irigaray's biological accounts of binary sex. According to Butler, this dualistic approach must be reexamined in discussions of gender practice.

This paper concludes with Butler's contribution: her redefinition of gender by pointing out the level of the gender phenomenon seen as ordinary sexuality produced and normalized on a heterosexual basis. Moreover, this paper discusses the importance of examining and describing the "bodies" and "actions" constructed in everyday life in order to demonstrate gender practice, which is necessary for the advancement of the sociology of gender.

Key words: Body, Actions, Judith Butler

(Received Dec. 23, 2010 / Accepted May. 18, 2012) 